YEARBOOK

of ANTITRUST

and REGULATORY

STUDIES

www.yars.wz.uw.edu.pl
Peer-reviewed scientific periodical, focusing on legal and economic issues of antitrust and regulation. Creative Commons Attribution-No Derivative Works 3.0 Poland License.

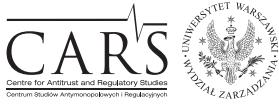

Centre for Antitrust and Regulatory Studies, University of Warsaw, Faculty of Management www.cars.wZ.uw.edu.pl

\title{
'A More Human Approach'. Human Rights, Obligations of the State and Network Neutrality in Europe
}

\author{
by
}

Andrzej Nałęcz*

\section{CONTENTS}

I. Introduction

II. The Internet as a tool to guarantee freedom of expression

III. Negative and positive obligations of the state in relation to human rights, and their influence on private actors

IV. Positive obligations of the state in securing freedom of expression related to regulating Internet access services under the European Convention

V. Negative and positive obligations of EU Member States to secure freedom of expression by regulating Internet access services and enforcing pertinent regulations

VI. Regulation 2015/2120 as a sign of European consensus - chance for a positive feedback loop between the EU and ECHR legal systems

VII. Conclusions

\section{Abstract}

The article explores the concept of the positive and negative obligations of the state in securing human rights, recognized in human rights literature, and in the judgments of the European Court of Human Rights. The concept is then applied to show the importance of securing freedom of expression in regulating Internet access services and enforcing pertinent regulations in EU Member States.

* Dr Andrzej Nałęcz, Assistant Professor, Faculty of Management, University of Warsaw; ANalecz@wz.uw.edu.pl, ORCID: 0000-0003-0553-2084. Article received: 6 June 2019, accepted: 9 September 2019. 
The author is of the opinion that economic arguments should not overshadow the need to secure the freedom of expression of the end-users of Internet access services.

\section{Resumé}

Larticle explore le concept des obligations positives et négatives de l'État en matière de défense des droits humains, reconnu dans la littérature sur les droits humains et dans les arrêts de la Cour européenne des droits de l'homme. Le concept est ensuite appliqué pour montrer l'importance de garantir la liberté d'expression dans la réglementation des services d'accès à Internet et dans l'application des réglementations pertinentes dans les États membres de l'UE. Lauteur est d'avis que les arguments économiques ne doivent pas occulter la nécessité de garantir la liberté d'expression des utilisateurs finals des services d'accès à Internet.

Key words: freedom of expression; Regulation 2015/2120; net neutrality; open Internet; Internet access service; positive obligations; negative obligations; European Convention on Human Rights; means of expression.

JEL: K20, K23, K38

\section{Introduction}

Network neutrality is the principle that requires Internet access service providers to treat all Internet traffic equally, without discrimination, thus letting end-users make their own choices as to what Internet content they access and distribute. The concept of network neutrality was forged by the jurisprudence of the United States of America. U.S. scholars were the first to notice the role of Internet access service providers as gatekeepers of the vast resources of the Internet, and the U.S. professor Tim Wu coined the term 'network neutrality' in his leading 2003 paper (Wu 2003). It comes as no surprise then that U.S. viewpoints and attitudes have been influencing the academic and regulatory discussions on network neutrality all over the world, also in the European Union. The U.S. proponents of network neutrality regulation seek to foster innovation among providers of Internet content, while the opponents fret about distorting competition between Internet access service providers. The whole discussion is framed in economic terms. This article challenges that approach. Europe needs its own theory of network neutrality, one representing 'a more human approach' rather than 'a more economic' one. Such a theory should be rooted in European values, and specifically 
in the Convention for the Protection of Human Rights and Fundamental Freedoms (hereinafter: European Convention), and the European Court's of Human Rights (hereinafter: ECHR) understanding of the state's negative and positive obligations regarding the safeguarding of the fundamental rights of individuals. The EU introduced a network neutrality regime in Regulation 2015/2120 laying down measures concerning open internet access. ${ }^{1}$ Even though the language of the EU provisions on network neutrality is close to that of the U.S., and despite the complicated relationship between the European Convention and the EU legal order, European values can and should be respected in the interpretation and enforcement of Regulation 2015/2120, and generally in regulating and offering Internet access services in all EU Member States.

The structure of the article is as follows. First, the role of the Internet as a tool to guarantee freedom of expression is presented. The Internet has become an essential means for expression, transforming the way people communicate, and share information and ideas. Second, the article discusses negative and positive obligations of the state in relation to human rights and their influence on private actors. In the author's opinion, states have an unambiguous positive obligation to ensure effective enjoyment of human rights, which may include requiring private actors to respect the rights of others, especially when such private actors are able to effectively influence the exercise of those rights. Third, the article analyses the positive obligations of states to secure freedom of expression in the context of Internet access under the European Convention. While the issue has not yet been comprehensively addressed by the ECHR, pertinent conclusions may be drawn from the ECHR's judgments in Mouvement Raëlien Suisse and Aplleby. Fourth, the article proposes how to draw on human rights in regulating Internet access services in the EU, and in applying Regulation 2015/2120. The need to not let economic arguments overshadow the state's obligation to secure human rights in the interpretation of Regulation 2015/2120 is discussed. Fifth, the article posits that in the future the ECHR may consider Regulation 2015/2120 as an indication of a European consensus on the existence of the state's positive obligations regarding regulating Internet access services.

1 Regulation (EU) 2015/2120 of the European Parliament and of the Council of 25 November 2015 laying down measures concerning open internet access and retail charges for regulated intra-EU communications and amending Directive 2002/22/EC and Regulation (EU) No 531/2012. ELI: http://data.europa.eu/eli/reg/2015/2120/2018-12-20. 


\section{The Internet as a tool to guarantee freedom of expression}

In the modern world, and especially in developed countries, the Internet has become one of the spheres of human existence. People use the Internet to communicate, and to acquire and disseminate ideas and information, related to their private, professional and public lives. From a legal point of view, one cannot help but recognize that a person exercises her fundamental human rights both in the physical and the digital environments, which are intertwined. Given the nature of the Internet as a medium for the spread of ideas and information, the foremost of those rights is freedom of expression. It is valued very highly in the modern society, even if there is little philosophical consensus as to why exactly that is the case (Nash, 2013, p. 444). John Stuart Mill's instrumentalist arguments refer to the importance of an unfettered debate for the discovery of truth, leading to better individual and social decisions (Barendt, 2007, 9). Alexander Meiklejohn's arguments for democracy place emphasis on political speech and the importance of the free flow of ideas for the political process and voting (Nash, 2013, p. 444). Finally, there are arguments linking freedom of expression to human dignity, personal autonomy, self-development and fulfillment. John Rawls's arguments for personal autonomy 'claim both that free speech has more than instrumental value, as an intrinsic aspect of individual autonomy, and further that such speech rights apply to all forms of speech, not solely political' (Nash, 2013, p. 444). Somewhat similarly, Ronald Dworkin argued that 'the case for free speech protection is grounded on fundamental background rights to human dignity and to equality of concern and respect' (Barendt, 2007, p. 14). The ECHR does not focus on a single axiological context of freedom of expression as a human right, affirming many, if not all of them. ${ }^{2}$

Even before the advent of the modern Internet, the ECHR recognized that freedom of expression 'applies not only to the content of information, but also to the means of dissemination, since any restriction imposed on the means necessarily interferes with the right to receive and impart information.' 3 Nowadays, the Internet has become one of such means of dissemination in fact, it may be considered the most important among them. The special relationship between the Internet and freedom of expression has been noted by the ECHR. According to the Court, access to the Internet has become

2 For example, see ECHR judgment of 28 September 1999, Case Öztürk v. Turkey, application no. 22479/93, ECLI: CE:ECHR:1999:0928JUD002247993, § 64.

3 ECHR judgment of 22 May 1990, Case Autronic v. Switzerland, application no. 12726/87, ECLI: CE:ECHR:1990:0522JUD001272687, § 47. 
an essential tool for the exercise of the freedom of expression, ${ }^{4}$ allowing 'participation in activities and discussions concerning political issues and issues of general interest. ${ }^{5}$ Some aspects of the Internet as a platform for the exercise of freedom of expression - such as the potential for user-generated expressive activity - are unprecedented. ${ }^{6}$ This transformative influence of the Internet on 'communication practices around the world' has also been noted by the United Nations Human Rights Committee (2011, para. 15). The ECHR has no doubt that '[i]n the light of its accessibility and its capacity to store and communicate vast amounts of information, the Internet plays an important role in enhancing the public's access to news and facilitating the dissemination of information in general, ${ }^{17}$ irrespective of its subject and potential commercial character. ${ }^{8,9}$ The ECHR also recently noted that 'Internet access has increasingly been understood as a right, and calls have been made to develop effective policies to attain universal access to the Internet and to overcome the digital divide (...).' While the ECHR does not expressly support or oppose the recognition of a right to Internet access, it 'considers that these developments reflect the important role the Internet plays in people's everyday lives.' ${ }^{10}$ Finally, the ECHR recognizes that 'an increasing amount of services and information is only available on the Internet.'11

${ }^{4}$ ECHR decision of 11 March 2014, Case Akdeniz v. Turkey, application no. 20877/10, ECLI: CE:ECHR:2014:0311DEC002087710, § 24.

5 ECHR judgment of 18 December 2012, Case Ahmet Yildirim v. Turkey, application no. 3111/10, ECLI:CE:ECHR:2012:1218JUD000311110, § 54.

${ }^{6}$ ECHR judgment of 16 June 2015, Case Delfi AS v. Estonia, application no. 64569/09, ECLI:CE:ECHR:2015:0616JUD006456909, § 110.

7 ECHR judgment of 10 June 2009, Case Times Newspapers LTD v. The United Kingdom, applications nos. 3002/03 and 23676/03, ECLI:CE:ECHR:2009:0310JUD000300203, § 27.

8 ECHR judgment of 10 January 2013, Case Ashby Donald and others v. France, application no. 36769/08, ECLI:CE:ECHR:2013:0110JUD003676908, § 34.

9 The ECHR comprehensively reiterated its understanding of the Internet's role for enhancing the exercise of the freedom of expression in the judgment of 1 December 2015, Case Cengiz and others v. Turkey, applications nos. 48226/10 and 14027/11, ECLI:CE:ECHR:2 015:1201JUD004822610, § 49, § 52, §55-56.

10 ECHR judgment of 19 January 2016, Case Kalda v. Estonia, application no. 17429/10, ECLI:CE:ECHR:2016:0119JUD001742910, §52. It should be noted that the ECHR does not expressly support or oppose the recognition of a right to Internet access - the Court simply notes that such a right is the subject of many discussions and policy statements.

11 'As evidenced by the fact that in Estonia the official publication of legal acts effectively takes place via the online version of Riigi Teataja and no longer through its paper version' - ibid. The ECHR reiterated this stance in its judgment of 17 January 2017, Case of Jankovskis v. Lithuania, application no. 21575/08, ECLI:CE:ECHR:2017:0117JUD002157508, $\S 49, \S 62$. 


\section{Negative and positive obligations of the state in relation to human rights, and their influence on private actors}

Traditionally, under the influence of early liberal philosophy of the Enlightenment (Ishay, 2004, p. 63-116), the obligations of the state relating to an individual's exercise of fundamental rights, including freedom of expression, were perceived as strictly negative. The state was simply required to refrain from unduly restricting the exercise of rights, especially in an arbitrary manner (Barendt, 2007, p. 22). Such traditional approaches still dominate in the U.S., rooted in the Constitution and its Amendments (Currie, 1986). As one American scholar put it, 'we do not have rights that positively obligate the state to do something. We do not have rights that require, rather than forbid, the state to take some action' (West, 2001, p. 1907). The last U.S. administration to embrace human rights and hint at accepting at least some positive obligations of the state was under President Jimmy Carter in the late 1970s (Hanum, 2019, p. 137-140). The refusal of the U.S. to ratify the 1966 International Covenant on Economic, Social, and Cultural Rights evidences American opposition to the concept of positive state action in relation to human rights, arising out of axiological differences between the U.S. and the international community (Alston, 1990, p. 367; Fields, 2003, p. 101). The Supremacy Clause (Article VI of the U.S. Constitution) declares international treaties, along with the Constitution and the laws of the U.S., to be the 'supreme Law of the Land.' Thus, provisions of treaties are enforceable in court, unless they are deemed to be non-self-executing, as elaborated upon by the Supreme Court in Foster v. Neilson. ${ }^{12}$ A treaty is non-self-executing generally when what 'it purports to do is only doable by statute,' or when 'it imposes an obligation that requires the exercise of nonjudicial discretion' (Vázquez, 2008, p. 602). Thus, by refusing to ratify a treaty involving unambiguous positive obligations of the state, the U.S. government preserves its strictly negative approach to human rights. ${ }^{13}$

Outside the U.S., especially in jurisprudence related to international human rights law, different approaches to the obligations of the state have developed. As Conçado Trindade (1998, p. 513) notes, the intention of the drafters of the 1948 Universal Declaration of Human Rights, which became the authoritative

12 Supreme Court judgment of 1829, Case Foster v. Neilson, 27 U.S. 253 (1829), https:// supreme.justia.com/cases/federal/us/27/253/.

13 However, it has been noted in the literature that with respect to some treaties, 'the non-self-executing doctrine has been stretched far beyond its proper application and original meaning to provide support for a theory under which treaties have no domestic legal force' (Carter, 2010, p. 389). A full discussion of the issue is beyond the scope of this article. 
model for further global and regional human rights treaties, was to place all rights on the same level, stressing their indivisibility and interdependence. Such an approach was advanced by the Tehran Proclamation (United Nations, 1968) and the Vienna Declaration (U.N. General Assembly, 1993). However, in his seminal 1977 article, Karel Vasak proposed the concept of generations of human rights, stressing the differences between them. Civil and political rights constitute the first generation and are negative in the sense that their respect requires that the state do nothing to interfere with individual liberties'. Second generation rights require 'positive action by the state to be implemented, as is the case with most social, economic and cultural rights' (Vasak, 1977, p. 29). ${ }^{14}$ Vasak's concept drove wedges between categories of human rights, and indicated that civil and political rights are strictly negative (Whelan, 2010, p. 211).

While it is common in international law literature to refer to the distinct 'generations' of rights (Fields, 2003, p. 40), another approach, more in line with the concept of the indivisibility and interdependence of rights, is to deny the utility, or even the possibility, of their division into various categories based on the scope of the obligations of the state necessary to secure those rights. Henry Shue noted 'that for every basic right ... there are three types of duties, all of which must be performed if the basic right is to be fully honored but not all of which must necessarily be performed by the same individuals or institutions.' These duties are to avoid depriving, to protect from deprivation, and to aid the deprived (Shue, 1980, p. 52). Shue's concept, later popularized by Asbjørn Eide in his 1987 paper The Right to Food as a Human Right (quoted in Koch, 2005, p. 84-85), ${ }^{15}$ requires the abandoning of the idea - which Shue considered a 'misdirected simplification' - that some rights are strictly negative while others are strictly positive. Indeed, 'it is impossible for any basic right - however "negative" it has come to seem - to be fully guaranteed unless all three types of duties are fulfilled' (Shue, 1980, p. 53).

Under the European Convention, as interpreted by the ECHR, states are subject not only to negative, but also to positive obligations with respect to human rights. This follows from Article 1 of the European Convention, which states that 'The High Contracting Parties shall secure to everyone within their

14 Vasak also indicated the emergence of a third generation of human rights, which he called 'rights of solidarity'. They 'include the right to development, the right to a healthy and ecologically balanced environment, the right to peace, and the right to ownership of the common heritage of mankind', and 'they can only be implemented by the combined efforts of everyone: individuals, states and other bodies, as well as public and private institutions' (Vasak, 1977, p. 29).

15 Eide fully assimilated Shue's concept, however he proposed a different nomenclature for the state's duties, calling them the obligations to respect, to protect, and to facilitate (Eide, 1996, p. 32-33). 
jurisdiction the rights and freedoms defined in Section I of this Convention.' The ECHR believes it does not have to develop a general theory of positive obligations of the state. ${ }^{16}$ It has also not provided an authoritative definition of them (Mowbray, 2004, p. 2). However, the characteristics of positive obligations may be derived from judgments in individual cases. Their prime characteristic 'is that they in practice require national authorities to take the necessary measures to safeguard a right, or, more precisely, to adopt reasonable and suitable measures to protect the rights of the individual' (Akandji-Kombe, 2007, p. 7). The stance of the ECHR on the existence of positive obligations of the state is linked to its commitment to ensure the effectiveness of the European Convention. According to the Court, 'the Convention is intended to guarantee rights that are practical and effective, not theoretical and illusory.' 17 Thus, the ECHR goes beyond pure textual interpretation in finding positive obligations in the Convention. Some positive obligations are indeed either 'expressly present in, or necessarily follow from the text of the Convention' (Harris et al., 2014, p. 22), for example, the obligation to protect the right to life by law under Article 2 (1) or to provide prison conditions and administer punishments that are not inhuman under Article 3. However, other positive obligations are the result of the ECHR's interpretation of the provisions of the European Convention (Harris et al., 2014, p. 22). The ECHR first determined that a state may have positive obligations under a provision of the European Convention utilizing a negative formulation in the so-called Belgian Linguistic Case. ${ }^{18}$ Since then, positive obligations of the state have been recognized by the ECHR in relation to many European Convention rights, including the right to liberty and security (Article 5), ${ }^{19}$ the right to respect for private and family life (Article 8), ${ }^{20}$ the freedom of thought, conscience and religion

16 ECHR judgment of 21 June 1988, Case Plattform 'Ärzte für das Leben' v. Austria, application no. 10126/82, ECLI:CE:ECHR:1988:0621JUD001012682, § 31.

17 The ECHR first used this formulation in its judgment of 9 October 1979, Case Airey v. Ireland, application no. 6289/73, ECLI:CE:ECHR:1979:1009JUD000628973, § 24, and has since quoted and paraphrased it many times.

18 ECHR judgment of 23 June 1968, Case "Relating to certain aspects of the laws on the use of languages in education in Belgium" v. Belgium, applications nos. 1474/62, 1677/62, 1691/62, 1769/63, 1994/63 and 2126/64, http://hudoc.echr.coe.int/eng?i=001-57525, part I-B, $\S 4$.

19 '... Article $5 \S 1$, first sentence, of the Convention must ... be construed as laying down a positive obligation on the State to protect the liberty of its citizens. ... The State is ... obliged to take measures providing effective protection of vulnerable persons, including reasonable steps to prevent a deprivation of liberty of which the authorities have or ought to have knowledge' - ECHR judgment of 16 June 2005, Case Storck v. Germany, application no. 61603/00, ECLI: CE:ECHR:2005:0616JUD006160300, § 102.

20 'The Court reiterates that the object of Article 8 is essentially that of protecting the individual against arbitrary interference by the public authorities. However, this provision does not merely compel the State to abstain from such interference: in addition to this primarily 
(Article 9), ${ }^{21}$ the freedom of expression (Article 10), ${ }^{22}$ and the freedom of assembly and association (Article 11). ${ }^{23}$ The textual formulation of none of these rights in the European Convention directly indicates the existence of positive obligations of the state.

What is especially interesting is the fact that the ECHR does not attempt to draw a clear line between rights that require negative and positive state action. In fact, the Court does not even consider it necessary to specify what type of obligations follow from the requirement to secure a specific right under the Convention. Be it positive or negative obligations, 'the applicable principles are broadly similar. In both contexts regard must be had to the fair balance that has to be struck between competing interests of the individual and the community as a whole; and in both contexts the state enjoys a certain margin of appreciation in determining the steps to be taken to ensure compliance with the Convention. ${ }^{24}$ Thus, the distinction between negative and positive obligations under the European Convention is blurred (Koch, 2005, p. 100).

Another important issue is the influence of human rights on relations between private actors. In general, human rights law does not impose horizontal duties - horizontal 'in the sense that they run between actors on the same legal plane', for example between two individuals (Knox 2008, 2). ${ }^{25}$ Specifically, it is generally accepted that the obligations under the European Convention

negative undertaking, there are positive obligations inherent in an effective respect for private or family life. These obligations may involve the adoption of measures designed to secure respect for private life even in the sphere of the relations of individuals between themselves' - ECHR judgment of 12 November 2013, Case Söderman v. Sweden, application no. 5786/08, ECLI:CE:ECHR:2013:1112JUD000578608, § 78.

21 '...through their inactivity, the relevant authorities failed in their duty to take the necessary measures to ensure that the group of Orthodox extremists led by Father Basil tolerated the existence of the applicants' religious community and enabled them to exercise freely their rights to freedom of religion' - ECHR judgment of 3 May 2007, Case 97 members of the Gldani Congregation of Jehovah's Witnesses and 4 others v. Georgia, application no. 71156/01, ECLI:CE: ECHR:2007:0503JUD007115601, § 134.

22 The Court considers that the positive obligations imply, inter alia, that States are obliged to create, while establishing an effective system of protection of authors and journalists, an environment conducive to the participation in public debates of all persons concerned, allowing them to express without fear their opinions and ideas - ECHR judgment of 14 September 2010, Case Dink v. Turkey, applications nos. 2668/07, 6102/08, 30079/08, 7072/09 and 7124/09, ECLI: CE:ECHR:2010:0914JUD000266807, § 137 (judgment in French, translation by the author).

23 Plattform 'Ärzte für das Leben' v. Austria judgment, supra note 16 above.

${ }^{24}$ ECHR judgment of 21 February 1990, Case Powell and Rayner v. the United Kingdom, application no. 9310/81, ECLI:CE:ECHR:1990:0221JUD000931081, § 41.

25 It is beyond the scope of this article to analyze the proposals to give a more direct horizontal dimension to international human rights law. For insight into the topic see Knox (2008). For an overview of the concept of third-party horizontal effect of fundamental rights, often called Drittwirkung in jurisprudence, see Engle (2009). 
itself 'are not imposed upon individuals' (Schabas, 2015, p. 105), ${ }^{26}$ since under Article 1 it is only the state parties that shall secure the rights prescribed by the Convention, and since 'applications complaining of violations can only be made against Contracting Parties to the Convention, that is, against States. ${ }^{27}$ However, that does not rule out the conclusion that the positive obligations of the state arising under the Convention may lead, and in some cases even need to lead, to the state imposing obligations on an individual, or more generally on a private actor, to respect the human rights of another individual. As Andrew Clapham noted, 'the privatization of functions such as law enforcement, health care, education, telecommunications, and broadcasting has meant in some cases the evaporation of controls which were placed on these sectors to ensure respect for civil and political rights' (Clapham, 2006, p. 8), and it 'has forced us to think again about the applicability of human rights law in the private sector' (Clapham, 2006, p. 3). Even if one rejects a direct horizontal effect of human rights, one may still agree that the more a horizontal relationship between two parties resembles a vertical one, the more it is justified for the state to intervene in order to secure the human rights of the weaker party of such a relationship (Florczak-Wątor, 2014, p. 60-61). Such an approach is compatible with the concept of the indivisibility and interdependence of human rights, as noted by Conçado Trindade (1998, p. 518 and 521), who stressed that ' $[\mathrm{i}] \mathrm{t}$ is necessary to continue defending all human rights against abuses of public power as well as any other type of power and domination', and that 'the State remains responsible for those violations that it fails to prevent.' While a full discussion of the United Nation's position on this issue is beyond the scope of this article, it should be mentioned that according to General comment No. 34 (United Nations Human Rights Committee 2011, para. 7), relating to freedom of expression under Article 19 of the International Covenant on Civil and Political Rights, states should 'ensure that persons are protected from any acts by private persons or entities that would impair the enjoyment of the freedoms of opinion and expression to the extent that these Covenant rights are amenable to application between private persons or entities.'

Many commentators of the European Convention agree on the growing extent to which positive obligations of the state rely on the duty to protect the rights of individuals from infringements by non-state actors (Clapham, 2006, p. 351). Indeed, Alastair Mowbray (2004, p. 225) pointed out that '[o] ne of the most prevalent types of positive obligations is the duty upon states to take reasonable measures to protect individuals from infringement of their

${ }^{26}$ For a discussion of this issue see Clapham (2006), p. 349-350.

27 Van Dijk, P., and G.J.H. van Hoof (1998). Theory and Practice of the European Convention on Human Rights. The Hague: Kluwer (quoted in Clapham 2006, 350). 
Convention rights by other private persons'. In the same vein, Jane Wright (2017, p. 70) noted that 'human rights obligations bind states in international law and ... those obligations may require states to control the acts of nonstate actors so that they in turn respect the rights of others'. However, 'the human rights obligation remains that of the state' (Wright 2017, 24). Similarly, according to William Schabas $(2015$, p. 90$)$ there is 'a duty to ensure that third parties do not infringe the rights of individuals'. Even though the ECHR 'does not consider it desirable, let alone necessary, to elaborate a general theory concerning the extent to which the Convention guarantees should be extended to relations between private individuals inter $s e^{2},{ }^{28}$ the conclusions of the cited authors are the natural result of the analysis of the judgments of the ECHR in individual cases. The Court requires states to take measures designed to protect people for example: from violent death under Article $2,{ }^{29}$ from ill-treatment under Article $3,{ }^{30}$ from violations of the respect for private life under Article $8^{31}$ - all at the hands not only of state actors, but also of private individuals.

\section{Positive obligations of the state in securing freedom of expression related to regulating Internet access services under the European Convention}

While the ECHR has recognized, firstly, the existence of at least some positive obligations of the state related to freedom of expression, and secondly, the importance of the Internet for its exercise, ${ }^{32}$ it has not yet comprehensively addressed the issue of the state securing this right through positive action in an Internet context. So far, the only judgment of the ECHR touching upon the matter was in the case of Editorial Board of Pravoye Delo and Shtekel v. Ukraine. The Court stated 'that the absence of a sufficient legal framework at the domestic level allowing journalists to use information obtained from the Internet without fear of incurring sanctions seriously hinders the exercise

28 ECHR judgment of 28 September 2001, Case VgT Verein gegen Tierfabriken v. Switzerland, application no 24699/94, ECLI:CE:ECHR:2001:0628JUD002469994, § 46.

29 ECHR judgment of 30 November 2004, Case Öneryıldiz v. Turkey, application no. 48939/99, ECLI:CE:ECHR:2004:1130JUD004893999, § 71 and 101.

30 ECHR judgment of 10 May 2001, Case $Z$ and others v. The United Kingdom, application no. 29392/95, ECLI:CE:ECHR:2001:0510JUD002939295, § 73.

31 ECHR judgment of 26 March 1985, Case $X$ and $Y$ v. the Netherlands, application no. 8978/80, ECLI:CE:ECHR:1985:0326JUD000897880, § 23.

32 As summarized in Part II above. 
of the vital function of the press as a public watchdog. ${ }^{33}$ Be that as it may, there certainly are grounds in the European Convention for a 'more human approach' to regulating Internet access services, based on positive obligations of the state.

When the ECHR considers what obligations the state should comply with to secure freedom of expression, and whether they are negative, positive, or both, the Court takes 'into account the nature of the freedom in question, its contribution to the public debate, the nature and scope of restrictions on freedom of expression, the existence of alternatives, and the weight to be given to the rights of others' (Schabas, 2015, p. 454).

Any reasonable determination of the state's obligations in securing freedom of expression should address the unique nature of the Internet as a means of communication, in particular its role as an essential tool for the exercise of freedom of expression, ${ }^{34}$ and its unprecedented potential for user-generated expressive activity. ${ }^{35}$ While the Internet indeed provides a place for the exercise of freedom of expression when other means are unavailable, as indicated by the ECHR in Mouvement Raëlien Suisse v. Switzerland, ${ }^{36}$ those other means may not be considered proper substitutes for the Internet, given its unique scope and reach. If one were denied access to the local press, or the possibility to distribute leaflets, or indeed the ability to display posters (as was the case in Mouvement Raëlien Suisse), one could still reach an audience on the Internet, and a much bigger audience at that. This would not be the case if the situation were reversed, that is if one sought to reach as big an audience through traditional media as on the Internet. This may simply not be ignored. The idea that the European Convention 'is a living instrument that must be interpreted according to present-day conditions has been a central feature of Strasbourg's case law from its very early days' (Letsas, 2013, p. 108). To deny the Internet's unique importance for the exercise of freedom of expression,

33 ECHR judgment of 5 May 2011, Case Editorial Board of Pravoye Delo and Shtekel v. Ukraine, application no. 33014/05, ECLI:CE:ECHR:2011:0505JUD003301405, §64. The ECHR considers the freedom of the press - not separately regulated in the European Convention - to be an integral element of the freedom of expression.

${ }^{34}$ Akdeniz v. Turkey judgment, supra note 4 above.

35 Delfi $A S$ v. Estonia judgment, supra note 6 above.

36 ECHR judgment of 13 July 2012, Case Mouvement Raëlien Suisse v. Switzerland, application no. 16354/06, ECLI:CE:ECHR:2012:0713JUD001635406. In the judgment, the ECHR addressed the refusal by police administration of authorization for the display of posters by an association. The Court ruled that the administration's actions did not constitute a violation of Article 10 of the European Convention. The ECHR stated that '[i]n view of the fact that the applicant association is able to continue to disseminate its ideas through its website, and through other means at its disposal such as the distribution of leaflets in the street or in letter-boxes, the impugned measure cannot be said to be disproportionate' $(\S 75)$. 
and its irreplaceability by other means of communication, would be to deny the reality of the world we live in.

In Appleby v. The United Kingdom, ${ }^{37}$ the ECHR addressed the issue of balancing freedom of expression and property rights. In the Court's opinion, 'the automatic creation of rights of entry to private property' does not necessarily follow from the recognition that 'demographic, social, economic and technological developments are changing the ways in which people move around and come into contact with each other.' However, if 'the bar on access to property has the effect of preventing any effective exercise of freedom of expression or it can be said that the essence of the right has been destroyed, the Court would not exclude that a positive obligation could arise for the State to protect the enjoyment of the Convention rights by regulating property rights.' To exemplify a situation where positive state action would be justified, the ECHR referenced the U.S. Supreme Court judgment in Marsh v. Alabama, which involved a corporate town, that is, a municipality wholly controlled by a private actor. ${ }^{38}$ This example is particularly interesting since it allows conclusions to be drawn pertinent to an Internet context. The Internet is a network of connected networks spanning the entire world, and built, owned and maintained mostly by private actors. Obviously, no single entity, private or public, controls the whole thing. However, an individual person's provider of Internet access services (usually called an Internet service provider, or ISP, in the literature) enjoys practically complete technical control over this person's service and its utility. Internet traffic travelling to and from the end-user may be blocked, slowed down, redirected or otherwise influenced through traffic management measures implemented in the network infrastructure. ${ }^{39}$ The end-user herself may not even know that traffic is being manipulated by the ISP (Van Schewick, 2010, p. 260), and so she may not realize the need to seek another ISP which does not infringe her rights. Thus, if ISPs were not obligated by the state to refrain from interfering with Internet traffic in at least some most intrusive ways, such as blocking, the end-user might be hindered in the exercise of her freedom of expression, or even prevented from it, and thus the essence of the right might be destroyed, given the Internet's unprecedented and essential role as a means of expression, mentioned above.

37 ECHR judgment of 6 May 2003, Case Appleby and others v. The United Kingdom, application no. 44306/98, ECLI:CE:ECHR:2003:0506JUD004430698, § 47.

38 Supreme Court judgment of 7 January 1946, Case Marsh v. Alabama, 326 U.S. 501 (1946), https://supreme.justia.com/cases/federal/us/326/501/.

39 A full discussion of internet traffic management and its technical implementation is beyond the scope of this article. For a concise overview of the issue see Belli (2016), especially 99-102. 
Commenting on Appleby, Jasper Sluijs argued by analogy that the state would only have an express positive obligation to intervene if an ISP were to block all expression on its network, effectively shutting down its operations, making impossible any use of the Internet (Sluijs, 2012, p. 105-106). While such a conclusion seems to be justified by directly applying the ECHR's Appleby reasoning - very firmly rooted in a brick-and-mortar environment to an Internet context, it very obviously ignores the pertinent and undeniable differences between expression in the material and digital worlds. Indeed, if one encountered a privately enforced obstacle to expressing oneself in the material world, one would simply have to travel outside the domain of the infringer to enjoy unfettered speech, as was the case in Appleby. However, in a digital environment, one may not leave the 'domain' of one's ISP, since the ISP is the gatekeeper of Internet access, a necessary intermediary between a person and her online expression. It may be possible to change one's ISP, however only on at least two conditions. Firstly, if one realizes the need to do so, which one may not if Internet traffic interference is clandestine, and secondly, if there is competition on the relevant market, which is not always the case. Still, that would only solve the problem if the other ISP did not interfere with the exercise of freedom of expression. The only way of absolutely guaranteeing this, would be for the state to obligate ISPs not to hinder expression.

\section{Negative and positive obligations of EU Member States to secure freedom of expression by regulating Internet access services and enforcing pertinent regulations}

The relationship between the European Convention, the EU and its Member States has always been complex, and has become even more so after the Charter of Fundamental Rights of the European Union (hereinafter: the Charter) acquired binding force in December 2009. ${ }^{40}$ All EU Member States are also Contracting Parties of the European Convention. Article 6 (2) TEU, as amended by the Treaty of Lisbon, obliges the EU to accede to the European Convention. This obligation harmonizes with Article 59 (2) of the European Convention, as amended by Protocol 14, under which the EU may accede to the Convention. The EU's accession 'would enhance the protection of human rights in Europe', firstly, by preventing divergences between the case

40 While the issue itself had to be mentioned here, a detailed discussion of the interaction of EU law and the European Convention system is beyond the scope of this article. For further clarification see Gragl (2013), Kuijer (2018), and Callewaert (2018). 
laws of the ECHR and the CJEU, secondly, by subjecting the EU and its institutions to external judicial supervision where human rights are concerned, and finally, by giving EU citizens the right to bring complaints against EU institutions directly before the ECHR (Gragl, 2013, p. 7). However, for now EU's accession has been put on hold, complicating the interaction between the European Convention and the EU legal order with its binding Charter (Kuijer, 2018).There are provisions both in the TEU and in the Charter that seek to resolve potential conflicts. Under Article 6 (3) TEU, '[f]undamental rights, as guaranteed by the European Convention for the Protection of Human Rights and Fundamental Freedoms and as they result from the constitutional traditions common to the Member States, shall constitute general principles of the Union's law.' Under Article 52 (3) of the Charter, '[i]n so far as this Charter contains rights which correspond to rights guaranteed by the Convention for the Protection of Human Rights and Fundamental Freedoms, the meaning and scope of those rights shall be the same as those laid down by the said Convention. This provision shall not prevent Union law providing more extensive protection.' After the Charter acquired binding force, whenever the Court of Justice was dealing with cases involving human rights claims, it relied on the Charter significantly more often than on the European Convention, while the reverse was the case before, in the period from 2000 to 2009 (De Búrca, 2013, p. 175). However, for the issues discussed in this article, the most important observation relating to the interplay of the various legal systems is that EU Member States are legally bound by the European Convention when applying EU law (Callewaert, 2018, p. 1710). The ECHR stated in Bosphorus that ' $[\mathrm{t}]$ he Convention does not ... prohibit Contracting Parties from transferring sovereign power to an international (including a supranational) organization in order to pursue cooperation in certain fields of activity,' and 'it has also been accepted that a Contracting Party is responsible under Article 1 of the Convention for all acts and omissions of its organs regardless whether the act or omission in question was a consequence of domestic law or of the necessity to comply with international legal obligations. ${ }^{41}$ Thus, the fact that Internet access services are regulated not by national legislation, but that of the EU, does not preclude the obligation of EU Member States to secure freedom of expression in the application of Regulation 2015/2120.

Internet access has been regulated in EU law, specifically by Regulation $2015 / 2120$. After several years of preparation and discussion, not without controversies (Marsden, 2017, 95-101), it introduced a network neutrality regime in the EU, not using the term itself, but rather opting for the

41 ECHR judgment of 30 June 2005, Case Bosphorus Hava Yollari Turizm ve Ticaret Anonim Şirketi v. Ireland, application no. 45036/98, ECLI: CE:ECHR:2005:0630JUD004503698, $\S 152-153$. 
designation of 'open Internet access.' Article 2 (2) defines an 'Internet access service' as a publicly available electronic communications service that provides access to the Internet, and thereby connectivity to virtually all end points of the Internet, irrespective of the network technology and terminal equipment used. Under Article 3 (1), end-users of Internet access services shall have the right to access and distribute information and content, use and provide applications and services, and use terminal equipment of their choice. The obligations of ISPs correspond to the rights of end-users, and involve, for example, the equal treatment of Internet traffic under Article 3 (3) first subparagraph. The provisions of Regulation 2015/2120 capture the essence of network neutrality, indicating the general-purpose functionality of Internet access services, prohibiting ISPs from arbitrarily interfering with Internet traffic, and allowing all end-users to access and distribute Internet content of their own choice. However, the language of Regulation 2015/2120, while referencing concepts within the scope of freedom of expression, such as the right to access and distribute information, does not specifically indicate that the aim of the Regulation was to secure the fundamental rights of Internet users in the EU. Recital (1) states that the Regulation 'aims to establish common rules to safeguard equal and non-discriminatory treatment of traffic in the provision of internet access services and related end-users' rights. It aims to protect end-users and simultaneously to guarantee the continued functioning of the internet ecosystem as an engine of innovation.' The fixation on innovation in the ecosystem clearly references the U.S. discussions on network neutrality, generally framed in economic terms, as exemplified by Wu and Yoo (2007). The Body of European Regulators for Electronic Communications (hereinafter: BEREC) acknowledges that Regulation 2015/2120 'observes the fundamental rights of, and the principles recognized in the Charter, notably ... the freedom of expression...' (BEREC, 2016, para. 20). BEREC also indicates that an infringement of end-user rights may occur if commercial or technical measures implemented by an ISP reduce the range and diversity of content and applications available to end-users, which 'may also concern the effect on freedom of expression and information, including media pluralism' (BEREC 2016, supra note 12 to para. 46). The lack of reference to fundamental rights in Regulation 2015/2120 itself, and their mention only as an obvious afterthought, and in fact as a literal footnote in the BEREC Guidelines, demonstrate an axiological deficit of the Regulation which may adversely affect its application.

In line with the uncontroversial concept of negative obligations of the state in ensuring the enjoyment of human rights, it is beyond any doubt that states are obligated not to violate human rights protected under the European Convention by the actions of their own organs (be they legislative, 
executive or judiciary), ${ }^{42}$ governmental organizations (which refers not only to 'central organs of the state, but also to decentralized authorities that exercise "public functions", regardless of their autonomy vis-á-vis the central organs'; this includes 'local and regional authorities'), ${ }^{43}$ and other bodies associated with the state, such as state-owned companies, unless they enjoy 'sufficient institutional and operational independence from the State.' ${ }^{4}$ Thus, if an Internet access service is provided by the state itself, freedom of expression of all end-users of the service must be respected for the state to meet its simple, negative obligation. Any arbitrary restrictions on the accessibility of Internet content through such a service would be incompatible with the European Convention. It is quite common in EU Member States for public bodies, such as municipalities, to provide wireless Internet access in public spaces. ${ }^{45}$ States also provide Internet access to households of some categories of end-users, specifically those threatened by digital exclusion. Such services sometimes come with restrictions related to the types of Internet content that may be distributed or accessed. ${ }^{46}$ It is the opinion of the author of this article that restrictions of this kind violate Article 10 of the European Convention, unless they may be justified under Article 10 (2). This position holds even if a given service falls outside the scope of Regulation 2015/2120, which may occur when the service is not publicly available, and thus does not constitute an Internet access service as defined in Article 2 (2) of Regulation 2015/2120. This applies, for example, to services offered exclusively to digitally excluded households after a vetting procedure (Nałęcz, 2017, p. 677-678).

As argued in Part IV above, in addition to negative obligations, states party to the European Convention also have a positive obligation to ensure the exercise of freedom of expression of everyone using Internet access services. This applies to services offered by private actors. The provisions of Regulation 2015/2120 requiring all ISPs to treat all Internet traffic equally, and to generally refrain from blocking Internet traffic and otherwise disrupting access to and distribution of Internet content, when indeed enforced by states allow for compliance with this positive obligation. However, the language of Regulation $2015 / 2120$ is ambiguous, and thus the practical effect of the Regulation

42 ECHR judgment of 18 February 2009, Case Andrejeva v. Latvia, application no. 55707/00, ECLI:CE:ECHR:2009:0218JUD005570700, § 56.

${ }^{43}$ ECHR decision of 23 September 2003, Case Radio France and others v. France, application no. 53984/00, ECLI:CE:ECHR:2003:0923DEC005398400, § 26.

${ }_{44}$ ECHR judgment of 30 November 2004, Case Mykhaylenky and others v. Ukraine, applications nos. 35091/02, 35196/02, 35201/02, 35204/02, 35945/02, 35949/02, 35953/02, 36800/02, 38296/02, and 42814/02, ECLI: CE:ECHR:2004:1130JUD003509102, § 44.

45 Providing wireless Internet access in public spaces is part of the EU's electronic communications policy, under the WiFi4EU initiative.

46 For examples of such restrictions see Nałęcz (2017). 
depends to a great extent on how its provisions are interpreted by state organs, including national regulatory agencies and the courts (Piątek, 2017, p. 8). The need to secure freedom of expression of the end-users of Internet access services under Article 10 of the European Convention should be considered when performing purposive interpretation of Regulation 2015/2120.

States have a positive obligation to establish and enforce effective measures to monitor the practices of all ISPs. For example, if a private actor ISP introduces a traffic management measure that blocks certain categories of traffic, resulting in an individual's inability to exercise freedom of expression, and the competent state authority, typically the national regulatory agency for electronic communications, fails to intervene, an infringement of the state's positive obligation may be identified.

One of the complex and controversial issues which may be clarified by reference to the need to secure freedom of expression is the practice of zerorating. ${ }^{47}$ It involves exempting traffic generated by some Internet content typically specific services or applications, rather than types thereof - from monthly data caps, which nowadays are common in mobile Internet access services, but may also apply to services offered in a fixed network (Marsden, 2016). ${ }^{48}$ Regulation 2015/2120 does not expressly address zero-rating. BEREC (2016, paras. 40-43) and commentators (Piątek, 2017, p. 171-72) consider zero-rating to be one of the commercial practices which under Article 3 (2) of Regulation 2015/2120 'shall not limit the rights of end-users' set out in Article 3 (1). In BEREC's opinion, '[a] zero-rating offer where all applications are blocked (or slowed down) once the data cap is reached except for the zero-rated application(s) would infringe Article 3 (3) first (and third) subparagraph [of Regulation 2015/2120]' (BEREC, 2016, para. 41). This is a sound interpretation, supported by the literal formulation of the provisions mentioned, and compatible with the human rights requirement that lawful traffic not be blocked. However, BEREC further indicates (2016, para. 43) that when assessing the compatibility of zero-rating and other agreements and commercial practices with Regulation 2015/2120, and their effect on end-user rights, national regulatory agencies should consider inter alia the scale of the practice. This is a reference to Recital (7), which proposes that the market position of the provider of Internet access services be taken into account when assessing whether its practices undermine the essence of end-user rights. This position is unacceptable from a human rights perspective. If the exercise of a human right is effectively prevented by a private actor, the economic position

47 For a theoretical discussion of zero-rating and a summary of the positions of the supporters and opponents of its admissibility in a network neutrality regime see Belli (2016).

48 The name 'zero-rating' refers to the effectively zero price of the data traffic of content subject to a zero-rating offer. 
of this entity vis-á-vis its competitors is completely immaterial. What matters is its position in relation to the person whose right has been infringed. If it is a position of effective power and domination, mentioned by Conçado Trindade and quoted in Part III above, the state should intervene. This analysis shows how excessive reliance on economic arguments may lead to the state failing in its obligation to secure human rights.

\section{Regulation 2015/2120 as a sign of European consensus - chance for a positive feedback loop between the $\mathrm{EU}$ and the ECHR legal systems}

There may in fact be a positive feedback loop effect between Regulation 2015/2120 and enforcing European Convention rights. When the ECHR reasons and decides on the outcome of a case, it often considers whether there is a European consensus on the matter at issue (Dzehtsiarou, 2018, p. 101). The court utilizes comparative legal studies through an analysis of the domestic laws and practices of the Contracting Parties (Dzehtsiarou, 2018, p. 105). It also takes into account international law, its application by regional courts other than the ECHR, reports of various organizations, and the laws and practices of states outside the Council of Europe (Dzehtsiarou, 2018, p. 106-107). Finally, and most importantly in the context of this article, the ECHR's judgments indicate that 'when the EU rules on a particular issue, such a ruling effectively forms a European consensus' (Dzehtsiarou, 2018, p. 119). Even though Regulation 2015/2120 does not explicitly mention the protection of freedom of expression as one of the aims of regulating Internet access services, its coming into force in all EU Member States is an unambiguous indication of a European consensus in denying ISPs the right to manage Internet traffic however they see fit. If the ECHR were to consider whether there exist positive obligations of the state in securing freedom of expression by regulating Internet access services, Regulation 2015/2120 would confirm their existence. Thus, the Regulation would strengthen the protection of freedom of expression in all parties of the European Convention, even those outside the EU, while at the same time EU Member States enforcing Regulation 2015/2120 would benefit from a strong axiological basis for their actions, represented by the stance of the ECHR. 


\section{Conclusions}

An analysis of human rights literature, and of the case law of the ECHR proved that, outside the U.S., it is quite common to admit that states not only need to refrain from infringing human rights, but they also should secure them through their own positive actions. Under the European Convention, the ECHR has long recognized both the negative and positive obligations of states, often without drawing a distinction between them. What matters is if people can effectively enjoy their fundamental rights. This may even involve the state obligating private actors to respect the human rights of others. In developed countries, the Internet has become an essential tool for the exercise of freedom of expression, with unprecedented potential for user-generated expressive activity. While the Internet is indeed 'an engine of innovation', as Recital (1) of Regulation 2015/2120 declares, much more importantly it is an engine of expression, which the Recitals do not mention.

Internet access is usually provided by private actors, who have the technical ability to restrict freedom of expression online. While the ECHR has not elaborated on the positive obligations of the state in securing freedom of expression by regulating Internet access services, this article aimed to show that such obligations exist under the European Convention. If the Convention is indeed to be a living instrument allowing the effective enjoyment of human rights, not only should states be subject to a negative obligation not to hinder expression in offering and regulating Internet access services, but they should also have a positive obligation to prevent private actor ISPs from engaging in practices that infringe on the freedom of expression of the end-users of their services. Internet access services have been regulated in the EU by Regulation 2015/2120. Even though the relationship between the legal systems of the European Convention and of the EU is nowadays complicated, EU Member States are bound by the European Convention when applying EU law. Thus, when enforcing Regulation 2015/2120 and interpreting its ambiguous provisions, specifically for the purpose of the assessment of the legality of agreements, commercial practices and traffic management measures, the need to secure the freedom of expression of everyone under Article 10 of the European Convention should be considered. There certainly is ample ground for a more human approach to the state's role in regulating the relations between private actors, and specifically between ISPs and end-users of Internet access services. While the economics of network neutrality may not be ignored in public policy, the economic issues should not overshadow the need to secure human rights. 


\section{Literature}

Akandji-Kombe, J.-F. (2007). Positive obligations under the European Convention on Human Rights. Strasbourg: Council of Europe.

Alston, P. (1990). U.S. Ratification of the Covenant on Economic, Social and Cultural Rights: The Need for an Entirely New Strategy. The American Journal of International Law 84(2), 365-393. Retrieved from: https://www.jstor.org/stable/2203459 (30.07.2019).

Barendt, E. (2007). Freedom of Speech. Oxford: Oxford University Press.

Belli, L. (2016). Net neutrality, zero rating and the Minitelisation of the internet. Journal of Cyber Policy 2(1), 96-122, https://doi.org/10.1080/23738871.2016.1238954.

BEREC. (2016). BEREC Guidelines on the Implementation by National Regulators of European Net Neutrality Rules. BoR (16) 127. Retrieved from: https://berec.europa.eu/ eng/document_register/subject_matter/berec/regulatory_best_practices/guidelines/6160berec-guidelines-on-the-implementation-by-national-regulators-of-european-netneutrality-rules (30.07.2019).

Callewaert, J. (2018). Do we still need Article 6(2) TEU? Considerations on the absence of EU accession to the ECHR and ITS. Common Market Law Review 55(6), 1685-1716. Retrieved from: https://johan-callewaert.eu/wp-content/uploads/2018/11/Do-we-stillneed-62-TEU_.pdf (30.07.2019).

Carter, W.M. Jr. (2010). Treaties as Law and the Rule of Law: The Judicial Power to Compel Domestic Treaty Implementation. Maryland Law Review 69(2), 344-389. Retrieved from: https://core.ac.uk/download/pdf/56358054.pdf (30.07.2019).

Clapham, A. (2006). Human Rights Obligations of Non-State Actors. Oxford: Oxford University Press.

Conçado Trindade, A.A. (1998). The interdependence of all human rights - obstacles and challenges to their implementation. International Social Science Journal 50(158), 513-523, https://doi.org/10.1111/1468-2451.00164.

Currie, D.P. (1986). Positive and Negative Constitutional Rights. University of Chicago Law Review 53(3), 864-890. Retrieved from: https://chicagounbound.uchicago.edu/cgi/ viewcontent.cgi? article $=5993$ (30.07.2019).

De Búrca, G. (2013). After the EU Charter of fundamental rights: The Court of Justice as a human rights adjudicator? Maastricht Journal of European and Comparative Law 20(2), 168-184, https://doi.org/10.1177/1023263X1302000202.

Dzehtsiarou, K. (2018). What is law for the European Court of Human Rights? Georgetown Journal of International Law 49(1), 89-134. Retrieved from: https://www.law.georgetown. edu/international-law-journal/wp-content/uploads/sites/21/2018/07/GT-GJIL180003.pdf (30.07.2019).

Eide, A. (1996). Human rights requirements to social and economic development. Food Policy 21(1), 23-39. htpps://doi.org/10.1016/0306-9192(95)00057-7.

Engle, E. (2009). Third Party Effect of Fundamental Rights. Hanse Law Review 5(2), 165-173. Retrieved from: https://papers.ssrn.com/sol3/papers.cfm?abstract_id=1481552 (30.07.2019).

Fields, A.B. (2003). Rethinking Human Rights for the New Millennium. New York: Palgrave Macmillan.

Florczak-Wątor, M. (2014). Horyzontalny wymiar praw konstytucyjnych, Kraków: Wydawnictwo Uniwersytetu Jagiellońskiego. 
Gragl, P. (2013). The Accession of the European Union to the European Convention on Human Rights. Oxford: Hart Publishing.

Hanum, H. (2019). Rescuing Human Rights. A Radically Moderate Approach. Cambridge: Cambridge University Press.

Harris, D.J., O’Boyle, M., Bates, E., Buckley, C., Harvey, P.H., Lafferty, M., Cumper, P., Arai, Y. and Green, H. (2014). Law of the European Convention on Human Rights. Oxford: Oxford University Press.

Ishay, M.R. (2004). The History of Human Rights. Berkeley: University of California Press. Knox, J.H. (2008). Horizontal Human Rights Law. The American Journal of International Law 102(1): 1-47. Retrieved from: https://www.jstor.org/stable/40007767 (30.07.2019).

Koch, I.E. (2005). Dichotomies, Trichotomies or Waves of Duties? Human Rights Law Review 5(1), 81-103, https://doi.org/10.1093/hrlrev/ngi004.

Kuijer, M. (2018). The challenging relationship between the European Convention on Human Rights and the EU legal order: consequences of a delayed accession. The International Journal of Human Rights. Advance online publication, https://doi.org/10. 1080/13642987.2018.1535433.

Letsas, G. (2013). The ECHR as a living instrument: its meaning and legitimacy. In: A. Føllesdal, B. Peters, and G. Ulfstein (eds.), Constituting Europe (pp. 106-141). Cambridge: Cambridge University Press, https://doi.org/10.1017/cbo9781139169295.005.

Marsden, C.T. (2016). Zero Rating and Mobile Net Neutrality. In: L. Belli and P. De Filippi (eds.), Net Neutrality Compendium. Human Rights, Free Competition and the Future of the Internet (pp. 241-260). Cham: Springer, https://doi.org/10.1007/978-3-31926425-7 18.

Marsden, C.T. (2017). Network neutrality: From policy to law to regulation. Manchester: Manchester University Press, https://doi.org/10.26530/oapen_622853.

Mowbray, A.R. (2004). The Development of Positive Obligations under the European Convention of Human Rights by the European Court of Human Rights. Oxford: Hart Publishing, https://doi.org/10.5040/9781472562920 .

Nałęcz, A. (2017). Aksjologia gminnych projektów bezpłatnego dostępu do Internetu. In: J. Zimmermann (ed.), Aksjologia prawa administracyjnego. Tom I. Warszawa: Wolters Kluwer.

Nash, V. (2013). Analyzing Freedom of Expression Online: Theoretical, Empirical, and Normative Contributions. In: W.H. Dutton (ed.), The Oxford Handbook of Internet Studies, edited by. Electronic book, n. p. Oxford: Oxford University Press, https://doi. org/10.1093/oxfordhb/9780199589074.013.0021.

Piątek, S. (2017). Rozporzadzenie UE Nr 2015/2120 w zakresie dostęu do otwartego internetu. Warszawa: C.H. Beck.

Schabas, W.A. (2015). The European Convention on Human Rights. A Commentary. Oxford: Oxford University Press, https://doi.org/10.5040/9781472561725.

Sluijs, J. (2012). Network Neutrality and European Law. Nijmegen: Wolf Legal Publishers (WLP).

United Nations. (1968). Final Act of the International Conference on Human Rights, Tehran, 13 May 1968. Retrieved from: https://www.refworld.org/docid/3ae6b36f1b.html (30.07.2019).

United Nations General Assembly. (1993). Vienna Declaration and Programme of Action, 12 July 1993, A/CONF.157/23. Retrieved from: https://www.refworld.org/ docid/3ae6b39ec.html (30.07.2019). 
United Nations Human Rights Committee. (2011). General comment no. 34, Article 19, Freedoms of opinion and expression, 12 September 2011, CCPR/C/GC/34. Retrieved from: https://www.refworld.org/docid/4ed34b562.html (30.07.2019).

Van Schewick, B. (2010). Internet architecture and innovation. Cambridge, MA: The MIT Press, https://doi.org/10.7551/mitpress/7580.001.0001.

Vázquez, C.M. (2008). Treaties as Law of the Land: The Supremacy Clause and the Judicial Enforcement of Treaties. Harvard Law Review 122(2): 599-695. Retrieved from: https://scholarship.law.georgetown.edu/facpub/979 (30.07.2019).

West, R. (2001). Rights, Capabilities, and the Good Society. Fordham Law Review 69(5): 1901-1932. Retrieved from: https://ir.lawnet.fordham.edu/flr/vol69/iss5/14/ (30.07.2019).

Whelan, D.J. (2010). Indivisible Human Rights. Philadelphia, PA: University of Pennsylvania Press, https://doi.org/10.9783/9780812205404.

Wright, J. (2017). Tort Law and Human Rights. Oxford: Hart, https://doi.org/10.5040/ 9781782257707.

Wu, T. (2003). Network neutrality, broadband discrimination. Journal on Telecommunications and High Technology Law 2, 141-179. Retrieved from: https://ssrn.com/abstract=388863 (30.07.2019).

Wu, T., and Yoo C. (2007). Keeping the Internet neutral?: Tim Wu and Christopher Yoo Debate. Federal Communications Law Journal 59(3), 575-592. Retrieved from: https:// www.repository.law.indiana.edu/fclj/vol59/iss3/6/ (30.07.2019). 